\title{
The Effect of Employee Religiosity and Organizational Culture on Employee Performance with Intrinsic Motivation as a Mediation Variable in Bank Syariah Indonesia (BSI) Ex BNI Syariah Head Office
}

\author{
Ramadhian Wijayanti and Mafizatun Nurhayati
}

\section{ABSTRACT}

This study aims to analyze the influence of aspects of employee religiosity and organizational culture on employee performance mediated by employee intrinsic motivation. The object of this research is the employees of the office of Bank Syariah Indonesia (BSI) ex BNIS Head Office. A total of 111 respondents filled out the questionnaire, the sample was taken using the Slovin formula from a total population of 153 employees from each division. This research was conducted from July 2020 to June 2021 at the office of Bank Syariah Indonesia (BSI) ex BNIS Head Office. The sampling technique used is purposive sampling. The data were analyzed using the SmartPLS (Partial Least Square) path analysis application. The results of this study indicate that the aspect of employee religiosity has a positive and significant effect on employee performance and organizational culture has a positive and significant effect on employee performance. Meanwhile, intrinsic motivation mediates between aspects of employee religiosity and organizational culture on employee performance. Intrinsic motivation mediates employee religiosity and organizational culture perfectly.

Keywords: Employee Performance, Intrinsic Motivation, Organizational Culture, Religiosity.
Submitted : August 21, 2021

Published : September 12, 2021

ISSN: $2507-1076$

DOI: $10.24018 /$ ejbmr.2021.6.5.1069

Ramadhian Wijayanti*

Master of Management, Mercu Buana

University, Jakarta Indonesia.

(e-mail: kuliahramadhian@gmail.com)

Mafizatun Nurhayati

Master of Management, Mercu Buana

University, Jakarta Indonesia.

(e-mail:

mafizatun.nurhayati@mercubuana.ac.id)

*Corresponding Author

\section{INTRODUCTION}

Indonesia, as the country with the largest Muslim population in the world, has the potential to be at the forefront of the Islamic finance industry. Increased public awareness of halal matter and strong stakeholder support are important factors in the development of the halal industry ecosystem in Indonesia. This includes Islamic banks. The existence of the Islamic banking industry in Indonesia itself has experienced a significant increase and development in the past three decades. Product innovation, service improvement, and network development show a positivetrend from year to year. In fact, the spirit to accelerate is alsoreflected in the number of Islamic banks that take corporate actions. There is no exception for Islamic banks owned by state-owned banks, namely Bank Syariah Mandiri, BNI Syariah.

Then as of February 1, 2021, Bank BNI Syariah, Bank BRI Syariah and Bank Mandiri Syariah officially merged and became Bank Syariah Indonesia (BSI). PT Bank Syariah Indonesia Tbk officially operates on February 1, 2021. After the merger, the composition of BSI shareholders consists of PT Bank Mandiri as the largest shareholder, namely 51.2\%, PT Bank Negara Indonesia 25\%, PT Bank Rakyat Indonesia 17.4\%, DPLK BRI-Sharia Syariah 2\% PT BNI Life Insurance and PT Mandiri Sekuritas $0.01 \%$ and the public $4.4 \%$.

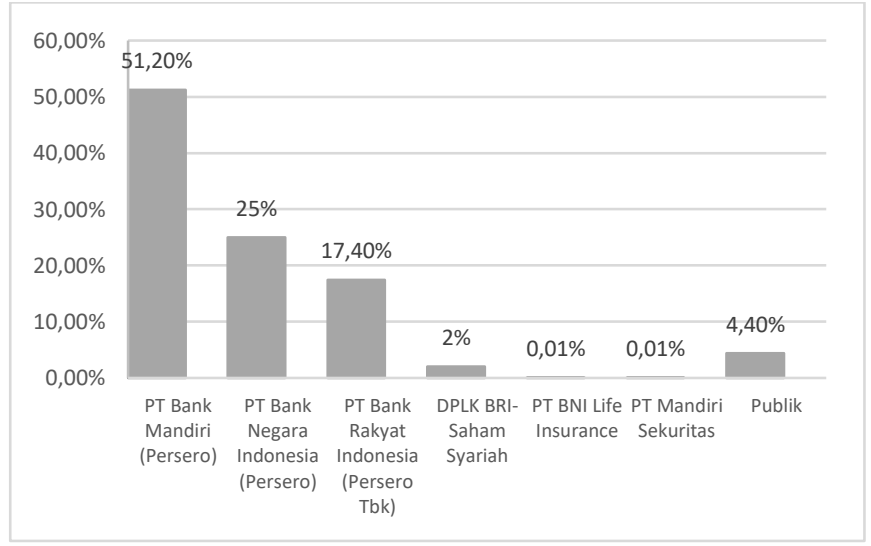

Fig. 1. Shareholders (\%). Source: [1].

The importance of quality human resources in the banking world has become a necessity. Given the increasingly rapid competition in the banking industry. The desire of banks to have a competitive advantage requires them to always improve the quality of their resources, while the quality of human resources is largely determined by the extent to which the applicable system is able to support and satisfy the wishes of employees and the company.

Merger of 3 BUMN Syariah Banks consisting of previous positions namely 6 Directors from Bank Syariah Mandiri, 2 Directors from Bank BNI Syariah and 2 Directors fromBank BRI Syariah. For the director of Compliance \&Human 
Capital, this comes from the previous director at Bank BNI Syariah. This indicates that the organizational culture built at Bank Syariah Indonesia adopts the organizational culture applied at Bank BNI Syariah.

If viewed based on the performance appraisal data obtained from the Human Capital Development (HCD) of Bank BNI Syariah before the merger into Bank Syariah Indonesia, there was an increase in employee performance with the criteria of very satisfactory (SM), satisfactory (M), Good (B) moderate (C) at Indonesian Islamic Bank (BSI). Although there is an increase in the assessment of getting better and increasing the assessment with satisfactory criteria, but there is an increase that is still lacking andsufficient and only good which increases more, ideally the performance appraisal is on very satisfactory criteria. This shows that the performance of employees at Bank Syariah Indonesia (BSI) has not been optimal with very satisfactory performance appraisal criteria, which is still low, and the increase is not too large.

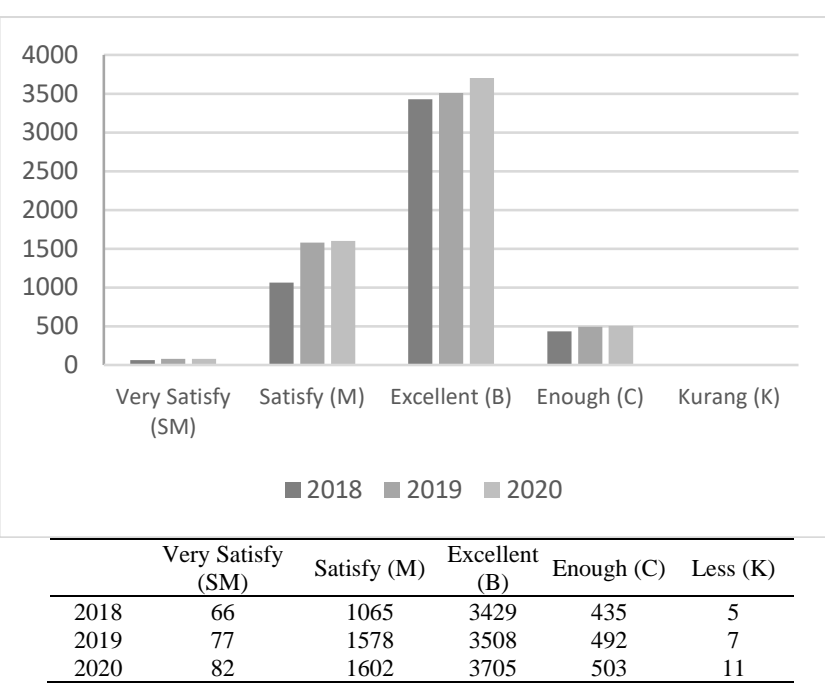

Fig. 2. Performance Employee Bank Syariah Indonesia Ex Bank BNI Syariah 2018-2020. Source: [2].

This study aims to analyze the influence of aspects of employee religiosity and organizational culture onemployee performance mediated by employee intrinsic motivation. This research study wants to know the effect of the influence between the variables to be studied. It can be concluded that there is a significant influence between the variables studied, namely the aspect of religiosity that has a positive and significant effect on employee performance.Then the aspect of religiosity has a positive and significant effect on intrinsic motivation. There is a significant influence of organizational culture on employeeperformance and organizational culture has a positive and significant effect on intrinsic motivation. Intrinsic motivation has a positive and significant effect on employee performance. Employee religiosity mediated by intrinsic motivation has a positive and significant effect on employee performance. Organizational culture mediated by intrinsic motivation has a positive and significant effect on employee performance.

This research is expected to provide benefits for related parties Contribution to science related to the influence of organizational culture religiosity and motivation on employee performance.

\section{LiterAtURE REVIEW AND HyPOTHESES DEVELOPMENT}

\section{A. Employee Performance (Employee Performance)}

Performance is the result of work achieved by a person based on job requirements, requirements commonly referred to as work standards, namely the level expected by certain jobs that must be completed and compared with the goals or objectives to be achieved. Furthermore, according to employee performance is the result of employee work in the form of input/output or can also be called work results in quantity and quality to achieve the targets set by the company so that performance in the company can achieve success [3]. Meanwhile, according to [4] performance or performance is a description of the level of achievement of the implementation of a program of activities or policies in realizing the goals, objectives, vision, and mission of the organization as outlined through the strategic planning of an organization. performance or performance is a description of the level of achievement of the implementation of a program of activities or policies in realizing the goals, objectives, vision, and mission of the organization as outlined through the strategic planning of an organization. Dimensions and indicators of employee performance according to [6] in [7] using several aspects of employee performance measurement namely Quality, Quantity, Timeliness, Cost effectiveness, Need for Supervision, Interpersonal impact

\section{B. Religiosity}

Religiosity is generally explained in terms of cognitions (religious knowledge, religious beliefs) that affect what one does with emotional attachment or emotional feelings about religion, and/or behavior, such as attending places of worship, reading scriptures and praying [5]. Meanwhile, according to [8] offers a definition of religion and spirituality as Religion is an organized system of beliefs, practices, rituals, and symbols designed to facilitate closeness to the sacred or transcendent (God, a higher power, ortruth/reality), and to foster understanding of relationships and responsibilities. answer one person to another in living together in the community. Dimensions and indicators of religiosity according to [10] namely Religious Belief (the ideological dimension), Religious Practice (the ritualistic dimension), Religious Feeling (the experiential dimension), Religious Knowledge (the intellectual dimension), and Religious Effect (the consequential dimension).

\section{Organizational Culture}

Organizational culture can be defined as a set of value systems (values), beliefs, assumptions (options), or norms that have long been in effect, agreed upon and followed by members of an organization as a guide to problem-solving behavior. organizational problems. Organizational culture is also called corporate culture, which is a set of norms that have been in effect for a relatively long time, shared by members of the organization (employees) as behavioral norms in solving organizational problems (companies). In organizational culture, values are socialized and internalized within members, animating each person in the organization. Thus, organizational culture is the soul of the organization and the soul of the members of the organization [11]. 
according to [12] organizational culture is a set of behaviors, feelings, and psychological frameworks that are deeply internalized and shared by members of the organization. Another definition put forward by [13] that organizational culture is a shared perception held by members organizational members of a system of shared meaning. Dimensions and indicators of organizationalculture that are used as an essential reference in understanding and measuring the existence of culture [13] namely innovation and decision making, stability, aggressiveness, team orientation, human orientation.

\section{Intrinsic Motivation}

Two-factor theory [13] put forward a theory of motivation based on the theory of two factors, namely hygiene and motivator factors. He divided Maslow's needs into two parts, namely lower-level needs (physical, security, and social)and higher-order needs (prestige and self-actualization) and suggested that the best way to motivate individuals is to satisfy higher-order needs. According to Hezberg, factors such as policies, company administration, and an adequate salary in a job will reassure employees. If these factors are not sufficient then people will not be satisfied [12]. Intrinsic motivation is the motivation that drives a person to achieve that comes from within the individual, which is better known as the motivational factor. According to the two-factor theory [13] Intrinsic motivation is Achievement Recognition, Work itself Responsibility, and Advancement.

\section{E. Hypothesis Development}

1) The Influence of Employee Religious Aspects on Employee Performance

The success of organizational management is largely determined by the utilization of human resources, especially in their performance. So, this is where it is very important for every leader of an organization to realize that there are techniques to be able to maintain employee performance, among others, by providing motivation so that they can carry out their duties according to the rules and directions. Religion is a person's religious system and beliefs. Religion is followed by rituals continuously following the rules that have been set through the books or teachings that are believed. It was further explained that religiosity is a meta- need that becomes the drive needed by humans for the emergence of a balance of immaterial behavior [14]. Research conducted by [15] found that there was a positive effect of employee religiosity on employee performance.

H1: Employee religiosity has a positive effect on employee performance.

\section{2) The Influence of Employees' Religious Aspects on Intrinsic Motivation}

Motivation as a series of processes that generate, direct, and maintain human behavior to achieve its goals. Motivation is also related to the choices made by individuals, the direction of the behavior they do. Motivation is something that encourages individuals (employees) to take an action to achieve certain goals. Whilereligiosity is the internalization of religious values in a person. This internalization is then actualized in daily actions and behavior, including work.
This is in accordance with research [16].

H2: Employee religiosity has a positive effect on EmployeeIntrinsic Motivation.

\section{3) The Influence of Organizational Culture on Employee Performance}

A strong organizational culture has an impact on company performance. Organizational culture is a framework that guides the behavior and decision-making of organizational members and directs their actions to achieve organizational goals. As research conducted by found that there is a positive influence of organizational culture onemployee performance [17].

H3: Organizational culture has a positive effect on employee performance.

\section{4) The Influence of Organizational Culture on Intrinsic Motivation}

Organizational culture is a value system that becomes a guide for those involved in the organization, becoming a differentiating factor against other organizations. With organizational culture, it is possible for individuals to change behavior because organizational culture is possible to be a factor that can have a positive or negative effect on individual organizational behavior. Organizational culture that is positive or negative can be a driving force (which motivates) someone related to the achievement oforganizational goals. Study [18] shows that empirically organizational culture has a significant effect on work motivation.

H4: Organizational culture has a positive effect on intrinsic motivation.

\section{5) The Influence of Employee Religiosity Through Mediation Variables Namely Employee Intrinsic Motivation on Employee Performance}

According to [19] with the existence of religiosity, a religious person should always try to do his best and not violate the rules in behaving and behaving in every activity, namely in accordance with the norms and rules that have been regulated in his religion. The religious factor itself can enable the realization of employee motivation that can achieve optimal performance.

H6: The role of intrinsic motivation that mediates the employee religiosity variable has a positive effect on employee performance.

\section{6) The Influence of Organizational Culture Through Mediation Variables, namely Employee Intrinsic Motivation on Employee Performance.}

Schein in [20] defines organizational culture as a pattern and basic assumptions-found or developed by a particular group to learn to cope with group problems of external adaptation and internal integration-that have worked well, relevant enough to be considered as correct to perceive, think and feel in relation to these problems. H7 The role of intrinsic 
motivation that mediates organizational culture variables has a positive effect on employee performance.

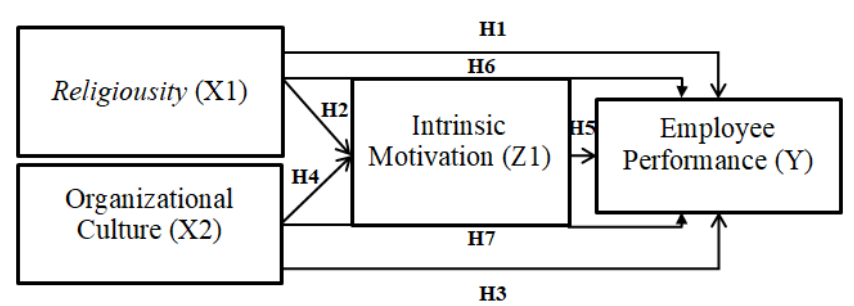

Fig. 1. Conceptual Model.

\section{RESEARCH METHODS}

The research uses an explanatory approach with quantitative research methods. The method of data collection in this study used a survey method with a questionnaire instrument, while the data used in this study was primary data. This study uses a personal questionnaire (personality administered questionnaires). In this study, respondents' answers were categorized into five categories using a Likert scale [21]. The population in this study were employees of Bank Syariah Indonesia which was divided into 5 work divisions. In sampling using purposive sampling (purposive sampling). The sampling criteria were based on permanent employees of Bank Syariah Indonesia who had the status of permanent employees for more than 1 year. Determination of the sample size using the Slovin approach. The number of research samples obtained is 111 respondents from a total population of 150 people, with an error tolerance limit of $5 \%$ and a confidence level of $95 \%$. The independent variables studied were Employee Religiosity (X1), Organizational Culture (X2). Thedependent variable studied is Employee Performance (Y). The mediating variable studied was Intrinsic Motivation (Z). The instrument test is one of the most important tools in quantitative research. The instrument test in this study consists of two steps, namely validity and reliability testing. Data analysis was carried out with Structural Equation Modeling-Partial Least Square (SEMPLS) because it hasthe ability to perform path analysis with latent variables to develop theory.

\section{RESEARCH RESULT}

\section{A. Descriptive Statistics Demographic Characteristics}

Table I is the result of responses from 111 respondents based on demographic characteristics, the number of employees who fill in the male respondents is 69 people with a percentage rate of $62 \%$, while the female sex is 42 people with a percentage rate of $38 \%$ with an age range of 21-30 years with a percentage of $60 \%$, while respondents aged 3040 years have a percentage of $27 \%$ with 36 respondents. And employees with age above 40 years have apercentage of $13 \%$ with the number of respondents amounting to 14 employees. Respondents were dominatedby the first strata education level with a total of 103 people with a percentage level of $93 \%$, while respondents with a second strata education level were 2 people with a percentage of $2 \%$ of the total respondents.
TABLE I: RESPONDENT CHARACTERISTIC

\begin{tabular}{ccc}
\hline Category & Description & Percentage \\
\hline \multirow{2}{*}{ Gender } & Man & $62 \%$ \\
& Woman & $38 \%$ \\
Age & $21-30$ years old & $60 \%$ \\
& $30-40$ years & $27 \%$ \\
& $>40$ years old & $13 \%$ \\
Education & Senior High School & $5 \%$ \\
& Strata I (S1) & $93 \%$ \\
& Strata II (S2) & $2 \%$ \\
Total & 111 & $100 \%$ \\
\hline
\end{tabular}

\section{B. Evaluation of the Measurement Model (Outer Model)}

The first stage of validity testing is testing convergent validity by checking the value of the loading factor with the condition that the value is $>0.5$ and the average variance extracted with the condition that the value is $>0.50$ [20]. If there is a loading factor below 0.50 it will be removed from the model, namely the opportunity indicator given by the organizational leader (MA1) and strict supervision (MRS1). Next, based on Table IV, the AVE section already has an AVE value $>0.50$. The conclusion is that the research has met convergent validity

The second stage of validity testing is the discriminant validity test through the AVE square root value, which must have the largest construct value in its own group by looking at the Fornell-Larcker value [22]. Table II shows that the square root value of AVE has the largest construct value in its own group. The conclusion in this study is discriminately valid.

Measurement of the reliability of a construct refers to the value of composite reliability and Cronbach's alpha, a reliable construct if the value is $>0.7$ [22]. In conclusion, this study already has a reliable construct because it has a value $>0.7$.

\begin{tabular}{ccccc}
\multicolumn{5}{c}{ TABLE II: FORNELL-LARCKER CRITERIA } \\
\hline & $\begin{array}{c}\text { Employee } \\
\text { Religiosity }\end{array}$ & $\begin{array}{c}\text { Organizational } \\
\text { culture }\end{array}$ & $\begin{array}{c}\text { Employee } \\
\text { performance }\end{array}$ & $\begin{array}{c}\text { Intrinsic } \\
\text { Motivation }\end{array}$ \\
\hline $\begin{array}{c}\text { Employee } \\
\text { Religiosity }\end{array}$ & $\mathbf{0 . 7 4 6}$ & & & \\
$\begin{array}{c}\text { Organizational } \\
\text { culture }\end{array}$ & 0.573 & $\mathbf{0 . 7 2 7}$ & & \\
$\begin{array}{c}\text { Employee } \\
\text { Performance } \\
\text { Intrinsic }\end{array}$ & 0.643 & 0.832 & $\mathbf{0 . 7 3 0}$ & \\
Motivation & 0.643 & 0.862 & 0.877 & $\mathbf{0 . 7 2 8}$ \\
\hline
\end{tabular}

\section{Evaluation of the Measurement Model (Inner Model)}

The value of R Square for the Intrinsic Motivation variable (Z) is 0.776 . Shows that $77.6 \%$ of the IntrinsicMotivation variable $(Z)$ can be moderately influenced by Employee Religiosity (X1) and Organizational Culture (X2) variables, while the remaining $22.4 \%$ is influenced by other variables outside the research. The R Square value of the Employee Performance variable (Y) is 0.801 . This shows that $80.1 \%$ of the Employee Performance variable (Y) can be moderately influenced by Employee Religiosity (X1), Organizational Culture (X2), and Intrinsic Motivation (Z) variables, while the remaining $27.8 \%$ is influenced by other variables. outside of the research.

The Goodness of Fit (GoF) value in this study of 0.6505 is included in the Godness of Fit $>0.36$. This indicates that the overall model is appropriate. 
TABLE III: VAlue of OUter LoAding, MEAN, Ave, Composite Reliability, CronbaCh AlF

\begin{tabular}{|c|c|c|c|c|c|c|}
\hline Variable & Indicator & Outer Loading & Mean & AVE & $\begin{array}{l}\text { Composite } \\
\text { Reliability }\end{array}$ & $\begin{array}{c}\text { Cronbach's } \\
\text { Alpha }\end{array}$ \\
\hline Employee & Understanding beliefs or ideologies (RB1) & 0.647 & 4.55 & 0.556 & 0.926 & 0.911 \\
\hline \multirow[t]{9}{*}{ Religiosity(X1) } & Accept the dogmatic things in his religion (RB2) & 0.705 & & & & \\
\hline & Ability to carry out religious orders (RE1) & 0.847 & & & & \\
\hline & Commitment to their religion (RE2) & 0.786 & & & & \\
\hline & Religious experience (RF1) & 0.812 & & & & \\
\hline & Feeling of closeness to God (RF2) & 0.737 & & & & \\
\hline & Knowledge about religion (RK1) & 0.773 & & & & \\
\hline & Efforts to increase knowledge (RK2) & 0.681 & & & & \\
\hline & Relying on aspects of religious values (RP1) & 0.664 & & & & \\
\hline & Behave in accordance with religious teachings (RP2) & 0.777 & & & & \\
\hline \multirow{13}{*}{$\begin{array}{c}\text { Organizational } \\
\text { Culture (X2) }\end{array}$} & Ability to take risks (MI1) & 0.668 & 4.25 & 0.528 & 0.935 & 0.924 \\
\hline & Organizational environment encourages innovation (MI2) & 0.798 & & & & \\
\hline & Maintenance (MS1) & 0.646 & & & & \\
\hline & Maintenance for decision making (MS2) & 0.751 & & & & \\
\hline & Initiative (A1) & 0.789 & & & & \\
\hline & $\begin{array}{c}\text { Organizational members compete with each other andwork } \\
\text { together (A2) }\end{array}$ & 0.704 & & & & \\
\hline & Members to work together (OT1) & 0.688 & & & & \\
\hline & Human factors in decision making (OT2) & 0.750 & & & & \\
\hline & Team problem solving discussion (OM1) & 0.766 & & & & \\
\hline & Good team problem solving (OM2) & 0.729 & & & & \\
\hline & Achievement of targets (outcomes) (OM3) & 0.511 & & & & \\
\hline & Job accuracy (OPD1) & 0.825 & & & & \\
\hline & Organizational analysis (OPD2) & 0.766 & & & & \\
\hline Intrinsic & Success (MA2) & 0.655 & 4.32 & 0.530 & 0.910 & 0.889 \\
\hline \multirow[t]{8}{*}{ Motivation (Z) } & Organizational Support (MR1) & 0.681 & & & & \\
\hline & Leadership Recognition (MR2) & 0.749 & & & & \\
\hline & Rewards (MW1) & 0.758 & & & & \\
\hline & Employee Confidence (MW2) & 0.752 & & & & \\
\hline & Work done (MW3) & 0.745 & & & & \\
\hline & Responsibilities (MRS2) & 0.674 & & & & \\
\hline & Development (MAD1) & 0.800 & & & & \\
\hline & Employee Participation (MAD2) & 0.729 & & & & \\
\hline Employee & Complete work quickly, precisely and efficiently (Q1) & 0.656 & 4.32 & 0.533 & 0.931 & 0.919 \\
\hline \multirow[t]{11}{*}{ Performance(Y) } & Work according to personal wishes and desires (Q2) & 0.742 & & & & \\
\hline & Work hard(Q3) & 0.771 & & & & \\
\hline & Quantity of work demanded (QT1) & 0.814 & & & & \\
\hline & Skills possessed by individuals (QT2) & 0.732 & & & & \\
\hline & Work based on standard time (TL1) & 0.673 & & & & \\
\hline & Complete work effectively and efficiently (TL2) & 0.832 & & & & \\
\hline & Effective and efficient use of resources (CE1) & 0.762 & & & & \\
\hline & Save costs incurred by the company (CE2) & 0.719 & & & & \\
\hline & Works well without any supervision (NFS1) & 0.713 & & & & \\
\hline & High self-esteem towards work (IM1) & 0.751 & & & & \\
\hline & Trying to achieve the best results at work (IM2) & 0.553 & & & & \\
\hline
\end{tabular}

TABLE IV: PATH COEFFicient VALUE, T-STATISTICS, AND P-VALUES

\begin{tabular}{|c|c|c|c|c|}
\hline $\begin{array}{c}\text { Relationships Between } \\
\text { Constructs }\end{array}$ & $\begin{array}{c}\text { Original } \\
\text { Sample }(\mathrm{O})\end{array}$ & $\begin{array}{l}\text { T Statistics } \\
(|\mathrm{O} / \mathrm{STDEV}|)\end{array}$ & $\begin{array}{c}\text { P- } \\
\text { Values }\end{array}$ & Influence \\
\hline \multicolumn{5}{|l|}{ Direct } \\
\hline $\begin{array}{c}\text { Employee Performance } \\
\stackrel{\rightarrow}{\longrightarrow} \text { Religiosity }\end{array}$ & 0.125 & 2,094 & 0.037 & Significant \\
\hline $\begin{array}{c}\text { Intrinsic Motivation } \longrightarrow \\
\text { Religiosity }\end{array}$ & 0.222 & 3,394 & 0.001 & Significant \\
\hline $\begin{array}{c}\text { Employee Performance } \\
\rightarrow \text { Organizational } \\
\text { Culture }\end{array}$ & 0.289 & 2,262 & 0.024 & Significant \\
\hline $\begin{array}{c}\text { Intrinsic Motivation } \longrightarrow \\
\text { Organizational Culture }\end{array}$ & 0.735 & 14.64 & 0.000 & Significant \\
\hline $\begin{array}{c}\text { Employee Performance } \\
\rightarrow \text { Intrinsic Motivation } \\
\text { Indirect (Indirect) }\end{array}$ & 0.547 & 4,535 & 0.000 & Significant \\
\hline $\begin{array}{c}\text { Religiosity } \longrightarrow \text { Intrinsic } \\
\text { Motivation } \longrightarrow \text { Employee } \\
\text { Performance }\end{array}$ & 0.121 & 3,124 & 0.002 & Significant \\
\hline $\begin{array}{c}\text { Organizational Culture } \rightarrow \\
\text { Intrinsic Motivation } \longrightarrow \\
\text { Employee Performance }\end{array}$ & 0.402 & 4,177 & 0.000 & Significant \\
\hline
\end{tabular}

TABLE V: VALUES OF $\mathrm{R}^{2}, \mathrm{Q}^{2}$, AND GOF

\begin{tabular}{cc}
\hline Variable & R Square \\
\hline Employee Performance $(\mathrm{Y})$ & 0.801 \\
Intrinsic Motivation $(\mathrm{Z})$ & 0.776 \\
\hline
\end{tabular}

$\mathrm{H} 1$ is accepted. Religiosity (X1) has a significant effect on Employee Performance (Y) at the head office of Bank Syariah Indonesia. The highest LF value is in the RE1 indicator (0.847), namely employees feel motivated to always rely on aspects of religious values, besides that the construct also strongly influences the RE2 indicator contained in the dimension of the effect of religiosity work (religious effect) with the result LF is 0.786 , namely employees have the ability to behave in accordance with religious teachings in social life at work. Then for the lowestLF value, namely the Religious Belief indicator (the ideological dimension) which means that understanding ideological beliefs does not encourage the inclusion of religious values in the work environment.

$\mathrm{H} 2$ is accepted that religiosity has a positive and significant effect on intrinsic motivation. the dimension which has a high LF score is the advancement dimension, where the construct has a very strong influence on the MAD1 and MAD2 indicators with LF results of 0.800; 0.729. The highest LF value is in the MAD1 indicator. Aspects of development in work by employees is what motivates employees to work, meaning that self- development provided by the company will make employeesmore motivated at work. With this, the 
company must be able to provide modifications and involve employees forreligious activities, development activities on a religious basis so that the motivation of the employees themselves is increasing.

$\mathrm{H} 3$ is accepted, namely organizational culture has a positive effect on employee performance. the dimension that has a high LF value is the dimension of attention to detail, where the construct has a very strong influence on the OPD1 OPD2 indicators with the LF results being 0.825, 0.766, respectively. The highest LF value is in the OPD1 indicator, namely the Company always prioritizes the aspect of accuracy in the organization. In addition, the construct also strongly influences the OPD2 indicator contained in the company's high analysis indicator in decision making with the LF result of 0.766 , namely the company prioritizes high analysis in every decision making.

$\mathrm{H} 4$ accepted that organizational culture has a positive effect on intrinsic motivation is acceptable. Based on the results of this study, the second dominant indicator value is aggressiveness, where company leaders have the ability to encourage organizational members to compete with each other and work together among organizational members so that the intrinsic motivation that arises in each employee will create an organizational culture that exists. each other toform synergy and harmony. While the lowest indicator value is human orientation (0.669) this shows that the company's leadership must involve employees more in every decision making in the organization. It is intended that the trust that exists is stronger both to fellow members of the organization and to the leadership of the company.

H5 can be accepted that intrinsic motivation has a positive and significant effect on employee performance. the most dominant indicator value on the intrinsic motivation variable is the indicator of development (advancement). this shows that employee development indicators have the greatest influence on employee performance, meaning that the more development the company provides to employees, especially in statements of potential for self-development that are interesting in work are motivating things for employees so that employee performance increases. The lowest indicator of intrinsic motivation, responsibility (responsibility), to make real responsibility as a driving factor for subordinates, leaders should avoid strict supervision by allowing subordinates to work alone as long as the work is possible and apply the principle of participation. The application of the principle of participation allows subordinates to fully plan and carry out their work.

H6 accepted that employee religiosity mediated byintrinsic motivation on employee performance has a positive and significant effect. The most dominant indicator value obtained on the religiosity variable is the effect of religiosity, this shows that the effect of religiosity in the form of behavior and actions taken by employees is able to encourage self-motivation and affect employee performance. This shows that religious beliefs are very important for employees, because if the religious beliefs of employees are higher, the motivation of employees to produce good performance or performance will be higher.

H7 organizational culture mediated by intrinsic motivation on employee performance is acceptable. The most dominant indicator value on organizational culture variable is attention to detail, and the dominant indicator value for intrinsic motivation is development (advancement) and the most dominant employee performance variable is quantity. This shows that intrinsic motivation through indicators of development (advancement) is able to partially mediate organizational culture on employee performance. This shows that employees who master and complete work quickly, accurately, and efficiently will continue to be reviewed by the company because in the culture of Bank Syariah Indonesia, the aspect of attention to detail is highly prioritized, and the company will always prioritize high analysis in decision making.

\section{CONCLUSION}

Based on the results of research at Bank Syariah Indonesia (BSI) ex-Bank BNI Syariah regarding the influence of employee religiosity aspects of organizational culture and intrinsic motivation as mediating variables on employee performance. The aspect of religiosity has a positive and significant effect on employee performance, which means that the better the aspect of employee religiosity, both in terms of behaving in accordance with religious teachings and guidance in social life, will further improve the performance of Bank Syariah Indonesia employees. The aspect of religiosity has a positive and significant effect on intrinsic motivation, which means that the aspect of religiosity itself that is implemented will increase employee motivation in the aspect of selfdevelopment and make employees' abilities and skills develop. Organizational culture has a positive and significant effect on employee performance, meaning that organizational culture becomes a behavioral guide for its members who are unconsciously applied in carrying out their activities. There is a relationship between organizational culture and the performance of employees or members of the organization, which can be reflected in the behavior of the organizational culture of Bank Syariah Indonesia. Organizational culture has a positive and significant effect on intrinsic motivation, namely corporate culture has the ability to encourage members of the organization to compete with each other and work together among members of the organization so that the intrinsic motivation that arises within each employee will create an organizational culture that is intertwined with each other. synergy and harmony. Intrinsic motivation has a positive and significant effect on employee performance, which means that the motivation that arises from within the employee through the stimulus given from the outside in this case the development indicators provided by the company affect employee performance. Employee religiosity mediated by intrinsic motivation has a positive and significant effect on employee performance, which means that employees who have a high level of religiosity, the motivation of employees to produce good performance or performance will also be higher.

\section{SugGeStion}

Company leaders are advised to always monitor and accommodate employees to always provide a supportive work environment for employees to strengthen personal 
religious knowledge for employees and continue to create a work culture that can support employees to be consistent and continue to improve religious aspects in the work environment. The company must be able to provide modifications to religious activities for development activities on a religious basis to accommodate employees so that employee motivation itself increases. It is intended that the values of religiosity that have been built will continue to be improved and continue to be consistent with employees. create an organizational culture that synergizes and works together for the betterment of the company by teaching employees to encourage members of the organization to compete and cooperate with each other, train employees to develop new innovative strategies, and train employees to study the company's competitors in order to get new ideas. Company leaders are advised to provide more training and development within the organization. As well as making developments that focus on self-development for each employee so that their abilities will continue to increase. Company leaders are advised to provide more training and development within the organization. As well as making developments that focus on self-development for each employee so that their abilities will continue to increase. Company leaders are advised to provide more training and development within the organization. As well as making developments that focus on self-development for each employee so that their abilities will continue to increase.

\section{LIMITATIONS AND FURTHER RESEARCH}

For further research interested in the same topic, it is recommended to explore the effect of external variables on employee performance and involve other variables such as spirituality, commitment, leadership style to predict employee performance. For further research, it is possible to develop a research model by developing a more varied population and sample so that it becomes useful input for the company. Suggestions for further research to expand the scope of research are not only former BNI Syariah Banks, but also Indonesian Islamic Banks as a whole, because the merger of these three Islamic State-Owned Banks will have many interesting phenomena to explore and develop for further research.

\section{REFERENCES}

[1] Financial statements as of March 31, 2021 https://www.irbankbsi.com/newsroom/BSI_Billingual_31_Maret_2021.pdf.

[2] Human Capital Development of Bank Syariah Indonesia ex Bank BNI Syariah "Employee Performance Appraisal", 2021.

[3] R. Iraawati, "Analisis pengaruh beban kerja terhadap kinerja karyawan operator pada PT Giken Precision Indonesia," Jakarta: Prodi Administrasi Bisnis Terapan, Jakarta: Applied Business Administration Study Program, 2017.

[4] Moeheriono, "Jakarta Competency-Based Performance Measurement: Grafindo Persada. 2012.

[5] Elci, M., "Effect of manifest Needs, Religiosity and selected demographics on hard working: an empirical investigation in Turkey. Journal of International Business Research, Vol. 6, number 2, 2007.

[6] Bernardin, H. a. Human Resource Management, New York, 2010, McGraw-Hill.

[7] Sudarmanto, Performance and Competency Development of HR: theory, dimensions, and implementation in organizations, 2009, Yogyakarta: Pustaka Pelajar.

[8] HG Koenig McCullough, M.a. Handbook of Religion and Health;
New York: Oxford University Press. 2012.

[9] Glock, C. Y, "On the study of religious commitment. Religious Education Research Supplement, 1960, ch. 98, pp. 98-110.

[10] MKillmann, "Thomas-Kilmann's Conflict Management Modes and their Relationship to Fiedler's Leadership Styles (basing on Estonian organizations), 2007.

[11] Osborne, D, "Crunching Bureaucracy: Five Strategies Towards Entrepreneurial Governance. (Translation of Ramelan Abdul Rosyid),

[12] Robins, "Management," (2006) Jakarta: Gramedia.

[13] Herzberg et al, F, "The Motivation to Work", 2008, USA: Wiley \& Son Inc.

[14] Woodward, M. R, "Analysis of the effect of workload on the performance of operator employees at PT Giken Precision Indonesia," Jakarta: Applied Business Administration Study Program., 2017.

[15] AAhad M. Osman-Gani, JH "stablishing linkages between religiosity and spirituality on employee performance". Kulliyyah of Economics and Management Sciences, 5-8. (2016).

[16] Zumrah, AK The effect of religiosity on trainees' reaction and motivation to transfer: Evidence from Malaysia. Journal of Islamic Accounting and Business Research, 2020, Vol. 11 No. 1, pp. 12- 26. https://doi.org/10.1108/JIABR-08-2017-0109.

[17] Harwiki, W. The Influence of Servant Leadership on Organizational Culture, Organizational Commitment, Organizational Citizenship Behavior and Employees' Performance (Study of Outstanding Cooperatives in East Java Province, Indonesia). Journal of Economics and Behavioral Studies, 2019, Vol. 5, No. 12, pp. 876-885.

[18] Emmy Juliningrum, AS. The Effect of Compensation, Organizational Culture, on Work Motivation and Employee Performance. Postgraduate Program, Faculty of Economics and Business, Universitas Brawijaya. 2013.

[19] Thoifah Amalia AN, Dimensions of Diamond Fraud and Smartphone Use Against Academic Fraud with Religiosity as a Moderating Variable. Economic Education Analysis Journal. 2019.

[20] Muchlas, M. Organizational Behavior. 2015. Yogyakarta: Gadjah Mada University Press.

[21] Now, UD Research Methods for Business: A Skill Building Approach, 7th Edition. New Jersey: Wiley. 2016.

[22] Ghozali \& Latan. Concepts, Techniques, Applications Using Smart PLS 3.0 for Empirical Research. Semarang: BP Undip. 2015. 